\title{
Nursing interventions and outcomes for pressure ulcer risk in critically ill patients
}

\author{
Intervenções e resultados de enfermagem para risco de lesão por pressão em pacientes \\ críticos
}

Luana Nunes Caldini ${ }^{1}$, Renan Alves Silva ${ }^{1}$, Geórgia Alcântara Alencar Melo ${ }^{1}$, Francisco Gilberto Fernandes Pereira $^{2}$, Natasha Marques Frota ${ }^{3}$, Joselany Áfio Caetano ${ }^{1}$

Objective: to establish relationships between nursing interventions and outcomes for the diagnosis Pressure ulcer risk in critically ill patients. Methods: longitudinal study of 63 patients in an intensive care unit. An instrument with clinical data of patients and the Braden Scale were used. The cross-mapping technique was used to establish the nursing interventions and outcomes for each risk factor. Results: four intervention/ outcome relationships were found for sensory perception; 11 for moisture; five for activity; six for nutrition; four for mobility; and three for friction/shear. Conclusion: thirty-three relationships related to the observed risk factors were found, with higher frequency of moisture. The relationships found with moisture were: urinary elimination, response to medication, wound healing: secondary intention, self-care: bathing, fluid, electrolyte and acid-base balance, intestinal continence and tissue integrity: skin and mucous membranes.

Descriptors: Nursing Process; Nursing Care; Pressure Ulcer; Risk Factors; Intensive Care Units; Critical Care.

Objetivo: estabelecer relações entre as intervenções e os resultados de enfermagem para o diagnóstico Risco de lesão por pressão em pacientes críticos. Métodos: estudo longitudinal, realizado com 63 pacientes, em uma unidade de terapia intensiva. Utilizou-se um instrumento com dados clínicos do paciente e a Escala de Braden. Realizou-se a técnica de mapeamento cruzado a fim de estabelecer os resultados e as intervenções de enfermagem para cada fator de risco. Resultados: encontraram-se quatro relações intervenções/resultados para percepção sensorial; 11 para umidade; cinco para atividade; seis para nutrição; quatro para mobilidade; e três para fricção/cisalhamento. Conclusão: identificaram-se 33 relações direcionadas aos fatores de risco observados, com maior frequência para umidade. As relações estabelecidas para a umidade foram: eliminação urinária, resposta à medicação, cicatrização de feridas: segunda intenção, autocuidado: banho, equilíbrio hídrico, equilíbrio eletrolítico e ácido-base, continência intestinal e integridade tissular: pele e mucosas.

Descritores: Processo de Enfermagem; Cuidados de Enfermagem; Lesão por Pressão; Fatores de Risco; Unidades de Terapia Intensiva; Cuidados Críticos.

\footnotetext{
${ }^{1}$ Universidade Federal do Ceará. Fortaleza, CE, Brazil.

${ }^{2}$ Universidade Federal do Piauí. Picos, PI, Brazil.

${ }^{3}$ Centro Universitário Estácio do Ceará. Fortaleza, CE, Brazil. 


\section{Introduction}

NANDA International defines Pressure ulcer risk (00249) as a state of vulnerability of cellular damage in the skin and underlying tissue resulting from compression of soft tissue, usually over a prominent bone, for a period of time that may cause local ischemia and, consequently, necrosis ${ }^{(1)}$. Although pressure ulcers are widely discussed in the literature and in the practice of care, there are still high levels of incidence and prevalence of pressure injuries, directly affecting the care dynamics and quality of life of patients at risk or with an already established injury ${ }^{(2)}$.

In this sense, knowing the risk factors aids in the accurate judgment for diagnostic inference and optimizes the nurses' clinical decision making, as well as direct preventive nursing interventions to decrease the incidence of this aggravation and obtain positive health outcomes.

Thus, the incorporation of nursing interventions/outcomes aimed at preventing pressure ulcers during hospitalization should be considered by nurses and their teams because they can benefit patients and reduce treatment costs ${ }^{(3)}$.

NANDA International points out that each nursing diagnosis to be included in the taxonomy must undergo a validation process, structured in the following phases: review of the diagnosis; decision on the type of diagnosis; choice of statement; definition of the diagnosis based on bibliography; identification of defining characteristics and of related and risk factors; preparation of a bibliographic review to support the inclusion of the diagnosis; and provision of examples of nursing outcomes and interventions for the proposed diagnosis ${ }^{(3)}$. In this sense, it is fundamental to identify the nursing outcomes listed in the Nursing Outcomes Classification (NOC) and the nursing interventions listed in the Nursing Interventions Classification (NIC).

There is a shortage of studies addressing the present theme using standardized nursing language directed at intensive care unit patients at risk of pressure ulcer ${ }^{(4)}$. The establishment of relationships between nursing interventions and outcomes of the diagnosis Pressure ulcer risk is, therefore, a timely goal, since it will provide a better support for the systematization of nursing care. Therefore, this study aimed to establish relationships between nursing interventions and outcomes for the diagnosis Pressure ulcer risk in critically ill patients.

\section{Métodos}

Longitudinal study with a quantitative approach developed at a clinical intensive care unit in a university hospital in northeast Brazil between March and October 2014. The study population was composed of patients hospitalized in this period.

Sampling was performed for convenience and included 63 patients who met the inclusion criteria: 18 years old or older; absence of pressure ulcer upon admission; score $\leq 16$ in the Braden Scale, a score that indicates the risk of pressure ulcer due in adults; and hospitalization for more than 48 hours. The exclusion criteria were: patients admitted only for maintenance of organ vitality when brain death was diagnosed.

The following instruments were used to collect data: a form with data on social variables (sex and age) and clinical variables (pre-existing chronic diseases, use of sedatives, cause of hospitalization, length of stay in the intensive care unit, use of vasoactive drugs, and bladder elimination devices) of the patients; and the Braden Scale. For the interpretation of the Braden Scale, the risk levels proposed by the authors of the scale were adopted in this study, namely: low risk > 16 points; moderate risk = 12 to 15 ; and high risk $\leq$ $11^{(5-6)}$. The subscales Sensory Perception, Activity, Mobility, Moisture and Nutrition had scores between one (less favorable for preserved skin) and four (more favorable for preserved skin), while in the case of friction and shear, the score ranged from one to three; the lower the number, the greater the impairment. The maximum possible sum is $23^{(5)}$.

Data were collected mostly in the morning, in 
alternate days of the week, preferably during bathing in order to allow better visualization of the areas of pressure ulcer risk, and to avoid interfering with the routine of the unit. However, nurses in the sector evaluated the skin at daily basis. A minimum of seven assessments were performed during the hospitalization period, and patients were followed up until discharge.

The nursing diagnosis Pressure ulcer risk was analyzed according to the factors listed in the Braden Scale. Then, the relationships between the expected outcomes based on the $\mathrm{NOC}^{(6)}$ and the nursing interventions, according to the $\mathrm{NIC}^{(7)}$, were established for each factor in the scale. In order to perform this step, nursing interventions and outcomes related to pressure ulcer prevention were cross-mapped ${ }^{(8)}$ with the NOC and NIC, according to the level of relatedness of the interventions and outcomes of each risk factor of the Braden Scale.

This technique of analysis consists in comparing data to identify similarity and validate objects of study in different contexts, and can be performed in three steps: identification of nursing prescriptions and goals linked to the selected risk factors and related to the development of pressure ulcer; comparison of each prescribed nursing care measure with interventions listed in the NIC and nursing goals with outcomes listed in the NOC; and organization of a list of NOC interventions and NIC outcomes for each risk factor studied ${ }^{(8)}$. The Statistical Package for Social Sciences version 21 was used to calculate the percentages, means and standard deviations of the dependent variables.

The study complied with the formal requirements contained in the national and international regulatory standards for research involving human beings.

\section{Results}

The majority of the patients were female $(61.9 \%)$ and had a mean age of 56.9 years $( \pm 17.28)$. The minimum and maximum ages were 19 and 87 ye- ars, respectively. The main reason for hospitalization was liver diseases (39.7\%), coming from a medical clinic unit (73.0\%). As for length of hospital stay, a mean of 8.29 days was observed, with a period of hospitalization between two and 10 days, with a minimum and maximum time of two and 33 days, respectively.

Most of the patients who were at high risk used sedative medications (31.8\%) and long-term bladder catheter (42.8\%). In the first assessment of Pressure ulcer risk during hospitalization, there was a predominance of patients at high risk (54.0\%). However, there was a higher number of patients at low and high risk at discharge, as evidenced by the increased scoring, with values of three and four in the factors.

The items that presented the worst Braden scale scores were Activity, with 100.0\% "bedridden"; and $60.3 \%$ presented "greater possibility" of friction and shear, justified by the lack of active mobilization of the patients, with perceptible adverse events caused by these mechanical forces, as well as the item Nutrition (52.4\%), since most were in zero diet, parenterally or enterally fed, or did not accept the full oral diet (Table 1).

Table 1 - Braden scale scores, per item, in the first and last assessment $(n=63)$

\begin{tabular}{lcccc}
\hline & \multicolumn{4}{c}{ Braden scale scores } \\
\cline { 2 - 5 } Variables & $\mathbf{1}$ & $\mathbf{2}$ & $\mathbf{3}$ & $\mathbf{4}$ \\
& $\mathbf{n}(\mathbf{\%})$ & $\mathbf{n}(\mathbf{\%})$ & $\mathbf{n ~ ( \% )}$ & $\mathbf{n}(\%)$ \\
\hline First assessment (admission) & & & & \\
Sensory perception & $22(34.9)$ & $9(14.3)$ & $16(25.4)$ & $16(25.4)$ \\
Moisture & $3(4.8)$ & $52(82.5)$ & $8(12.7)$ & - \\
Activity & $63(100.0)$ & - & - & - \\
Nutrition & $33(52.4)$ & $20(31.7)$ & $7(11.1)$ & $3(4.8)$ \\
Mobility & $27(42.9)$ & $19(30.2)$ & $16(25.4)$ & $1(1.6)$ \\
Friction and shear* & $38(60.3)$ & $23(36.5)$ & $2(3.2)$ & - \\
Last assessment (discharge) & & & & \\
Sensory perception & $11(17.4)$ & $11(17.4)$ & $19(30.2)$ & $22(35)$ \\
Moisture & $1(1.6)$ & $40(63.4)$ & $15(23.8)$ & $7(11.2)$ \\
Activity & $48(76.3)$ & $10(15.9)$ & $5(7.8)$ & - \\
Nutrition & $28(44.4)$ & $16(25.4)$ & $12(19.1)$ & $7(11.1)$ \\
Mobility & $19(30.1)$ & $15(23.8)$ & $21(33.4)$ & $8(12.7)$ \\
Friction and shear * & $30(47.6)$ & $25(39.7)$ & $8(12.7)$ & - \\
* The subscale has a classification up to score three & &
\end{tabular}

After assessment of the patients using the Braden Scale, the prevalence of the nursing diagnosis Pressure ulcer risk was $82.6 \%$ in the first assessment, considering cases of high and moderate risk, and $74.1 \%$ in the last clinical assessment (Table 2). 
Table 2 - Classification of the pressure ulcer risk and development of pressure ulcer according to admission and discharge/death $(\mathrm{n}=63)$

\begin{tabular}{lcccc}
\hline \multirow{2}{*}{ Braden assessment } & \multicolumn{4}{c}{ Pressure ulcer risk } \\
\cline { 2 - 5 } & High & Moderate & Low & Total \\
\hline Admission & $34(54)$ & $18(28.6)$ & $11(17.5)$ & $63(100.0)$ \\
Discharge & $28(51.9)$ & $12(22.2)$ & $14(25.9)$ & $54(100.0)$ \\
Death & $5(55.6)$ & $2(22.2)$ & $2(22.2)$ & $9(100.0)$ \\
\hline
\end{tabular}

The majority of patients were discharged from the hospital due to a favorable condition (85.7\%), with a pressure ulcer risk of $74.1 \%$. It was also verified that $27.8 \%$ of the patients who were discharged by favorable condition developed the outcome of the diagnosis; whereas, $22.2 \%$ of the patients who died had developed pressure ulcer.

When considering the risk factors based on the Braden Scale items, the relationships between expected nursing outcomes and interventions were established (Figure 1). It was found that some risk factors presented common nursing interventions and outcomes, due to the association with pressure ulcer risk of.

\begin{tabular}{|c|c|c|}
\hline Risk factors & Nursing outcomes (NOC) & Nursing interventions (NIC) \\
\hline \multirow{4}{*}{ Sensory perception } & Neurological status: peripheral (0917) & Peripheral sensitivity control (2660) \\
\hline & Risk control (1902) & Pressure Control (3500) \\
\hline & Tissue integrity: skin and mucous membranes (1101) & Skin care: topical treatment (3584) \\
\hline & Risk detection (1908) & Pressure ulcer prevention (3540) \\
\hline \multirow{10}{*}{ Moisture } & Urinary elimination (0503) & $\begin{array}{l}\text { Catheter care: urinary }(1876) \\
\text { Care with the perineum }(1750)\end{array}$ \\
\hline & \begin{tabular}{|l|} 
Response to medication (2301) \\
\end{tabular} & Control of medications (2380) \\
\hline & Wound healing: secondary intention (1103) & Care with injuries: closed drainage (3662) \\
\hline & Self-care: bathing (0301) & Bathing (1610) \\
\hline & Fluid balance (0601) & Electrolyte monitoring (2020) \\
\hline & \begin{tabular}{|l|} 
Electrolyte and acid-base balance (0600) \\
\end{tabular} & Hydroelectrolytic control (2080) \\
\hline & \begin{tabular}{|l|} 
Intestinal Continence (0500) \\
\end{tabular} & Care with intestinal incontinence (0410) \\
\hline & Tissue integrity: skin and mucous membranes (1101) & Skin supervision (3590) \\
\hline & $\begin{array}{l}\text { Self-care: bathing (0301) } \\
\text { Self-care: hygiene (0305) } \\
\end{array}$ & Self-care assistance: bathing / hygiene (1801) \\
\hline & Urinary incontinence (0502) & Care with urinary incontinence (0610) \\
\hline \multirow{4}{*}{ Activity } & $\begin{array}{l}\text { Locomotion: walking (0200) } \\
\text { Mobility (0208) }\end{array}$ & Exercise therapy: walking (0221) \\
\hline & Rest (0003) & Care with bed rest (0704) \\
\hline & Body positioning: self-initiated (0203) & $\begin{array}{l}\text { Positioning (0840) } \\
\text { Positioning: wheelchair (0846) }\end{array}$ \\
\hline & Body mechanics performance (1616) & Promotion of exercise (0200) \\
\hline \multirow{6}{*}{ Nutrition } & Weight: body mass (1006) & Nutritional control (1100) \\
\hline & \begin{tabular}{|l|} 
Nutritional status: biochemical indicators (1005) \\
\end{tabular} & Nutritional monitoring (1160) \\
\hline & \begin{tabular}{|l|} 
Gastrointestinal Function (1015) \\
\end{tabular} & Administration of total parenteral nutrition (1200) \\
\hline & Nutritional status (1004) & Nutritional therapy (1120) \\
\hline & Self-care: feeding (0303) & Self-care assistance: feeding (1803) \\
\hline & Intestinal elimination (0501) & Control of diarrhea (0460) \\
\hline \multirow{5}{*}{ Mobility } & Body positioning: self-initiated (0203) & Positioning (0840) \\
\hline & \begin{tabular}{|l|} 
Joint movement (0206) \\
\end{tabular} & Exercise therapy: joint mobility (0224) \\
\hline & Coordinated Movement (0212) & Exercise therapy: muscle control (0226) \\
\hline & Body mechanics performance (1616) & Exercise promotion: stretching (0202) \\
\hline & Tissue integrity: skin and mucous membranes (1101) & Prevention of pressure ulcer (3540) \\
\hline \multirow{3}{*}{ Friction and shear } & Tissue integrity: skin and mucous membranes (1101) & Prevention of pressure ulcer (3540) \\
\hline & Risk control (1902) & Pressure control (3500) \\
\hline & State of comfort: physical (2010) & Massage (1480) \\
\hline
\end{tabular}

Figure 1 - Relationship between NOC outcomes and NIC interventions for the nursing diagnosis Pressure ulcer risk according to the Braden Scale 


\section{Discussion}

A limitation of the study is the low sample coverage and the geographical and institutional restriction with which the research was conducted, representing, therefore, a local reality in which the nursing process in critical units is in the phase of implantation.

In the assessment of the skin, there was a predominance of patients with thin and swollen skin, thus at risk of developing pressure ulcer. A study carried out in the critical care units of a hospital showed that the majority of the patients had skin changes, with a prevalence of patients with pale and dry $\operatorname{skin}^{(9)}$.

According to an integrative review on pressure ulcer risk assessment, the Braden Scale serves as a predictive instrument to infer this diagnosis ${ }^{(10)}$, evaluating items such as sensory perception, nutrition, moisture, activity, friction and shear and mobility. In fact, the use of the Braden scale is highlighted as an important strategy in the prevention of pressure ulcers in critical units ${ }^{(5)}$.

The subscale sensory perception can be altered by the use of drugs, causing a reduction in the sensation of pain and discomfort, as well as a stimulus to change position to relieve the areas exposed to excessive pressure, what makes them more susceptible to the formation of ulcers. It was observed in the study that the majority of patients at risk of pressure ulcer had completely impaired sensory perception, and thus unable to indicate points of discomfort caused by pressure. The item sensory perception was also pointed out in another research as the one posing the greatest risk among the patients who developed pressure ulcer $^{(11) .}$

In a study carried out in the intensive care unit of a school hospital, it was observed that $77.8 \%$ of the evaluated patients were at high risk for developing pressure ulcer according to the Braden scale in the subscales sensory perception, moisture and mobility ${ }^{(12)}$. A Brazilian study reported the occurrence of pressure ulcers in public and private hospitals, according to Braden subscales, and showed a statistically significant association between development of pressure ulcer and complete limitation of sensory perception $^{(13)}$.

In the subscale activity, it was observed that all the patients were bedridden. This finding was similar to another study, in which the incidence of bedridden patients who developed pressure ulcer was $82.6 \%$. That study also reported that all patients were restricted to the bed, to the chair and with difficulty to change position should be considered patients at risk in the risk assessment ${ }^{(13)}$.

As for mobility, the patients were completely immobilized on admission. As a consequence, they were at a higher risk of developing pressure ulcer. This cause-effect relationship is characterized as an expected outcome that greatly enhances the development and worsening of the lesions under study ${ }^{(14)}$. Decubitus changes and stretching techniques of the upper and lower limbs were decisive for modifying the level of impairment of mobility: from completely immobile to very limited and slightly limited.

The subscale Friction and shear evaluates the movement of the patient regarding the ability to leave the skin clear of contact with the surface of the bed or the chair when moved alone or with help ${ }^{(5)}$. The performance of decubitus changes, the stimulus to active movement and the assistance in passive movement; promotion of comfortable position to the patient; assistance in ambulation and raising of the lower limbs were observed among the care measures carried out to reduce the risk of the factors related to activity, mobility, friction and shearing ${ }^{(15)}$.

Regarding the item moisture, the present study found a predominance of patients scoring two. This fact may be related to skin exposure to moisture, mainly to urine and faeces, associated with abrasion forces such as friction and shear, which predispose to increased irritation, maceration and ulceration ${ }^{(16)}$. Among the nursing interventions directed to the risk factor moisture, there were: care with catheters: uri- 
nary; care with the perineum; control of medications; care with injuries: closed drainage; bathing; electrolyte monitoring; hydroelectrolytic control; care with intestinal incontinence; skin supervision; self-care assistance: bathing/hygiene; and care with urinary incontinence.

In a study of content validation of nursing interventions directed at patients at risk of developing pressure ulcer, the interventions that presented a relation with moisture were: skin supervision, bathing, care with urinary incontinence. Contradictory results were found in the literature, where the electrolytic control, hydroelectrolytic control, and control of medications were discarded in a the scenario of practice with patients at risk of developing pressure ulcer ${ }^{(17)}$.

Moisture is observed to behave as one of the determinants factors for pressure ulcers, a condition that makes the skin more fragile and susceptible to friction and maceration. Moisture, whether derived from products or physiological secretions and fluids, causes softening and maceration of the skin, reducing the tensile strength of the skin, making it fragile to compression, friction and shear, besides promoting the growth of microorganisms that harm its integrity ${ }^{(10)}$.

Therefore, care with urinary catheter and related injuries is highly recommended, as well as closed drainage in intestinal incontinence and urinary incontinence as priority interventions to decrease or minimize the risk of pressure ulcers in critically ill patients. Moreover, moisture was the risk factors that presented a higher percentage of preventive interventions ${ }^{(17)}$.

In the item Nutrition, the following nursing interventions were identified: nutritional control; nutritional monitoring; administration of total parenteral nutrition; nutritional therapy; self-care assistance: feeding; and control of diarrhea. Similar results were found in another study, whose intervention nutritio- nal therapy was identified as a priority, while nutritional control, administration of total parenteral nutrition and control of diarrhea were suggested ${ }^{(17)}$.

The analysis of the current edition of the Nursing Interventions Classification shows no connection between the intervention Pressure ulcer prevention and the nursing diagnosis Impaired physical mobility, although they are related to the positioning and rest. Therefore, it is recommended that Pressure ulcer prevention be considered a suggested rather than optional intervention.

The study made it possible to observe that nursing interventions and outcomes should be directed towards observable risk factors, aiming at breaking the chain of risk or minimizing possible adverse events during hospitalization. As implications for clinical practice, the study identified the most appropriate nursing interventions for the planning of preventive measures for patients at risk of developing pressure ulcers.

\section{Conclusion}

Based on the cross-mapping, there were four intervention/outcome relationships for the risk factor of sensory perception; eleven for moisture; five for activity; six for nutrition; four for mobility; and three for friction and shear. The main risk factor was moisture, the following expected results: urinary elimination, response to medication, wound healing: secondary intention, self-care: bathing, fluid balance, electrolyte and acid-base balance, intestinal continence and tissue integrity: skin and mucous membranes, self-care: hygiene, urinary continence, locomotion: walking, mobility, rest, body positioning: self-initiated, body mechanics performance, weight: body mass, nutritional status: biochemical indicators, gastrointestinal function, nutritional status, self-care: feeding, and intestinal elimination. 


\section{Collaborations}

Caldini LN, Silva RA and Melo GAA contributed to the design of the work, data collection and organization. Pereira FGF and Frota NM contributed to the data analysis and interpretation. Caetano JA contributed to the writing, critical review of the intellectual content and final approval of the version to be published.

\section{References}

1. Herdman TH, Kamitsuru S. NANDA International nursing diagnoses: definitions and classification, 2015-2017. Oxford: Wiley-Blackwell; 2014.

2. Shafipour V, Ramezanpour E, Gorji MA, Moosazadeh M. Prevalence of postoperative pressure ulcer: a sysrematic review and metaanalysis. Electr Phys. 2016; 8(11):3170-6. doi: http://dx.doi.org/10.19082/3170

3. Eduardo AHA, Napoleão AA, Carvalho EC. Nursing interventions for patients with erectile dysfunction after radical prostatectomy: integrative review. Enferm Glob [Internet]. 2016 [cited 2017 Jan. 05];15 (2):424-39. Available from: http://revistas. um.es/eglobal/article/viewFile/230811/192571

4. Santos CT, Almeida MA, Lucena AF. The Nursing Diagnosis of risk for pressure ulcer: content validation. Rev Latino-Am Enfermagem. 2016; 24: e2693:1-8. doi: http://dx.doi.org/10.1590/15188345.0782 .2693

5. Braden B, Bergstrom N. Aconceptual schemafor the study of the etiology of pressure sores. RehabilNurs. 2000; 25(3):105-10. doi: http://onlinelibrary. wiley.com/doi/10.1002/j.2048-7940.2000. tb01879.x/abstract

6. Moorhead S, Johnson M, Mass M, Swanson E. Nursing Outcomes Classification (NOC). Saint Louis: Mosby, Elsevier Health Sciences; 2012.

7. Bulechek G, Butcher H, Dochterman J, Wagner C. Nursing interventions classification (NIC). Saint Louis: Mosby, Elsevier Health Sciences; 2012.
8. Silva TN, Santana RF, Santos GLA, Silva LF, Bastos GM, Garcia TD. Intervenções de Enfermagem no programa de gerenciamento de crônicos: mapeamento cruzado. Rev Rene. 2014; 15(6):9981006. doi: http://dx.doi.org/10.15253/21756783.2014000600013

9. Araújo TM, Araújo MFM, Caetano JA. Using the Braden Scale and photographs to assess pressure ulcer risk. Rev Esc Enferm USP. 2012; 46(4):85864. doi: http://dx.doi.org/10.1590/S008062342012000400011

10. Alves AGP, Borges JWP, Brito MA. Assessment of risk for pressure ulcers in intensive care units: an integrative review. Rev Pesqui Cuid Fundam On line. 2014; 6(2):793-804. doi: http://dx.doi. org/10.9789/2175-5361.2014v6n2p793

11. Pedrosa IL, Silva MSML, Araújo AA, Schwanke CHA, DeCarli GA, Gomes I. Pressure ulcers in elders an in non-elders: a historical cohort study. Online Braz J Nurs. 2014; 13(1):82-91. doi: http://dx.doi. org/10.5935/1676-4285.20144111

12. Silva MLN, Caminha RTÓ, Oliveira SHS, Diniz ERS, Oliveira JL, Neves VSN. Pressure ulcer in intensive care unit: analysis of incidence and injuries installed. Rev Rene [Internet]. 2013 [cited 2017 Aug. 12]; 14(5):938-44. Availbale from: http:// www.revistarene.ufc.br/revista/index.php/ revista/article/view/1341/pdf_1

13. Menegon DB, Bercini RR, Santos CT, Lucena AF, Pereira AGS, Scain SF. Braden subscales analysis as indicative of risk for pressure ulcer. Texto Contexto Enferm. 2012; 21(4):854-61. doi: http://dx.doi. org/10.1590/S0104-07072012000400016

14. Pedro S, Simões C, Alvarelhão J, Costa C, Simões CJ, Figueira J, et al: Pressure ulcer risk assessment: retrospective analysis of Braden Scale score in Portuguese hospitalised adult patients. J Clin Nurs. 2015; 24(21-22):3165-76. doi: http:// dx.doi.org/10.1111/jocn.12927

15. Zambonato B, Assis M, Beghetto M. Association of braden subscales with the risk of development of pressure ulcer. RevGaúchaEnferm. 2013;34(2):2128. doi: http://dx.doi.org/10.1590/S198314472013000200003 
16. Menegueti MG, Martins MA, Canini SRMS, BasileFilho A, Laus AM. Infecção urinária em Unidade de Terapia Intensiva: um indicador de processo para prevenção. Rev Rene [Internet]. 2012 [citado 2017 Jan. 05]; 13(3):632-8. Disponível em: http:// www.revistarene.ufc.br/revista/index.php/ revista/article/view/730/pdf
17. Bavaresco T, Lucena AF. Nursing Intervention Classifications (NIC) validated for patients at risk of pressure ulcers. Rev Latino-Am Enfermagem. 2012; 20(6):1109-16. doi: http://dx.doi. org/10.1590/S0104-11692012000600013 